\title{
KH. ABD. RAHMAN PAKKANNA: ULAMA PEMIKIR PRAKTIS DAN PEKERJA PROFESIONAL
}

\author{
KH. ABD.RAHMAN PAKKANNA: \\ THE PRACTICAL THINKERS ULAMA AND PROFESSIONAL WORKERS
}

\author{
Muhammad As'ad \\ Balai Penelitian dan Pengembangan Agama Makassar \\ Jl. A.P. Pettarani No. 72 Makassar \\ Email: malitbang@yahoo.com
}

Naskah diterima tanggal 3 September 2016. Naskah direvisi tanggal 28 Oktober 2016. Naskah disetujui tanggal 9 November 2016.

\begin{abstract}
Abstrak
Penelitian ini bertujuan untuk mengungkap berbagai hal berkaitan dengan kehidupan KH. Abd. Rahman Pakkanna, seorang ulama yang besar jasanya dalam pembinaan masyarakat di Kabupaten Soppeng, terutama masyarakat Ganra. Penelitian ini merupakan penelitian deskriptif kualitatif dengan pendekatan sejarah. Teknik pengumpulan data yang dipergunakan adalah wawancara, studi dokumen dan pustaka serta observasi. Hasil penelitian ini mengungkap kehidupan dan aktivitas KH. Abd. Rahman Pakkanna sebagai sorang ulama pemikir praktis dan pekerja profesional. Ia seorang anak petani desa dari Soppeng yang berhasil membina pendidikan anak-anaknya sehingga menjadi sarjana, bahkan dua orang S3. Jenjang pendidikan yang diikutinya ialah pesantren dan madrasah pada berbagai tempat yang mengantarnya menjadi ulama. Kegiatannya sebagai guru agama dimulainya sejak menjadi santri pada MAI Sengkang dan berlangsung sampai tua. Statusnya sebagai PNS hanya sebagai penunjang aktivitasnya di bidang pendidikan. Selain sebagai guru ia juga sebagai tukang jahit yang terampil dan sebagai petani profesional. Jasanya sangat besar dalam pembinaan dan pendidikan masyarakat Ganra melalui Perguruan Islam Ganra dan masjid Ganra, sebagai tulang punggung pembangunan pisiknya dan sebagai pengajar pada keduanya. Berbagai sifat terpuji menjadi bahagian hidupnya, antara lain: sangat hormat kepada gurunya, toleran dalam masalah khilafiyah, pekerja keras dan profesional, percaya diri dan berusaha tidak bergantung pada orang lain. Ia termasuk ulama Fiqhi yang dalam pengetahuan agamanya, menjadi rujukan masyarakatnya, bukan hanya dalam masalah keagamaan, sebagai tempat bertanya dan panutan, tetapi juga dalam masalah sosial dan ekonomi masyarakat. Keikhlasannya diakui oleh masyarakat sehingga sangat percaya padanya. Modal sosial berupa keikhlasan, amanah, dan keterampilan yang dimilikinya sangat membantu pembangunan pisik, baik pada Perguruan Islam Ganra maupun pada Masjid Taqwa Ganra yang dipercayakan padanya dalam waktu yang lama.
\end{abstract}

Kata Kunci: ulama, biografi, KH. Abd. Rahman Pakkanna, Ganra.

\begin{abstract}
Abstrack
This study aims to reveal various matters relating to the life of KH. Abd. Rahman Pakkanna, a cleric of great merit in the development of society in Soppeng, especially the Ganra. This research is a qualitative descriptive approach to history. Data collection techniques used were interviews, documents and literature study and observation. The results of this study reveal the life and activity of KH. Abd. Rahman Pakkanna as a practical thinker clerical and professional workers. He was a farm boy from the village of Soppeng successfully foster their children's education so as to graduate, even two doctorates. Qualification which is attended Islamic school on the places that drove him into clerics. Activities as religious teachers to be students at commencement since MAI Sengkang and lasts until old age.Civil service status only as a support activity in the field of education. Aside from being a teacher he is also a skilled seamstress and as a professional farmer. Services is very large in coaching and education community through the Islamic education of Ganra and mosques Ganra, as the backbone of the physical development and as an instructor at both. Various good character being part of his life, among others: very respectful to his teacher, tolerant in matters khilafiyah, hardworking and professional, confident and trying not to depend on others. He included clerics Fiqhi deep religious knowledge, became the reference society, not only in religious matters, as a place to ask and role models, but also in the social and economic problems. Sincerity is recognized by the public so strongly trust
\end{abstract}


him. The social capital of sincerity, trust, and the skills they have very helpful in building physical, either on the Islamic education of Ganra and at Masjid Taqwa Ganra entrusted to him in a long time.

Keywords: ulemas, biography,KH. Abd Rahman Pakkanna, Ganra

\section{PENDAHULUAN}

$\mathrm{U}$ lama sebagai pemimpin umat Islam telah banyak mendapat perhatian oleh para pakar dan peneliti dalam kajiankajiannya berkaitan dengan kepemimpinan Islam. Mereka mengakui pentingnya peran dan posisi yang dimainkan oleh para ulamadalam kehidupan masyarakatnya sebagai tokoh yang berpengaruh. Ulama memainkan peran sebagai tokoh sentral dalam masyarakatnya, yang diharapkan menjadi rujukan masyarakat dalam pelbagai persoalan ummat, sehingga pengetahuan yang dimiliki oleh ulama harus selalu sejalan dengan perbuatannya. Dengan demikian, tidaklah berlebihan kiranya ketika Cliffort Geertz memposisikan ulama sebagai agen budaya (cultural brokers). Ulama adalah penghubung yang paling objektif antara lokalitas masyarakat dengandunia luar, dengan berperanuntuk memberikan pemahaman melalui pembacaannya yang menyeluruh terhadap segala persoalan kepada masyarakat agar tidak tersesat (Turmudi. 2004: 2 dan Ahmad, 2009: 1-2), hal ini dipertegas kembali oleh Horikoshi yang menilai bahwa seorang ulama haruslah mampu menggerakkan masyarakat dan mengarahkannya kepada kebenaran dan kebaikan, dalam pengertian sebagai pemimpin ummat, yang tidak sekadar berfungsi sebagai perantara-agen budaya (1987: 241).

Ketokohan ulama terkait dengan fungsinya sebagai wasatul anbiya, penerus misi kenabian. Sebagai pewaris nabi, merekalah yang harus bersungguh-sungguh memahami hakekat ajaran Allah yang disampaikan oleh Nabi Muhammad saw. Mereka pulalah yang paling mantap dalam hal-hal memberi makna, menetapkan arah dan menggariskan langkah-langhkah perjuangan untuk menegakkan Islam, baik dalam upaya pelestarian maupun pengmalannya untuk mencapai kesejahteraan dan kebahagiaan hidup di dunia dan di akherat (Abdullah ed, 1983: 18). Kata alim dan derivasinya diapresiasi/disebutkan dalam Alquran sebanyak 823 kali, bersamaan dengan beberapa ungkapan yang mempunyai kesesuaian makna antara lain al-aql, al-'itibar, al-fikr, al-basyar, al-tadabbur, al-nazhr, dan al-dzikr. Kata عالم alim yang sekaligus merupakan akar kata dari ulama oleh pakar ahli
Alquran Raghib Al-Ashfahani mendefenisikannya sebagai sebuah pengetahuan yang memiliki suatu hakikat (tth: 127). Terminologi Ulama itu sendiri berasal dari akar kata علم, yang dapat diinterpretasikan sebagai seorang yang mengetahui, sementara dari segi etimologi, ulama adalah bentuk jamak dari kata alim عالم. Alim adalah isim fail dari kata dasar علم (ilmu). Jadi عالم alim adalah orang yang berilmu. Sementara itu, علماء culama dapat dipahami sebagai orang yang berilmu (Al-Husain, t.th: 88). Kata alim juga bermakna sebagai pengaruh dan atau kemuliaan yang dimiliki orang tertentu yang tidak dimiliki oleh orang lain kebanyakan, sehingga hal tersebut dapat dipahami dengan mengasosiasikannya sebagai seseorang yang dapat memadukan pengetahuan dan pengalamannya di saat bersamaan (Ibn Manzur al-Afriqi, t.th: 416).

Pengakuan masyarakat terhadap ketokohan ulama sebagai panutan karena sistem pendidikan yang diberikan kepada masyarakat menyentuh hal yang sangat esensial dalam hidup manusia, yaitu manusia sebagai hamba Allah dan sebagai khalifahnya di bumi. Kedua fungsi ini dapat berjalan dengan baik jika iman sebagai fondasi tertanam dengan baik. Iman yang baik akan memunculkan akhlak atau moralitas yang tinggi yang dapat dijadikan panutan. Akhlak atau moralitas inilah yang terpancar dari diri seorang ulama.

Akhlak atau moral yang terpanacar itu mengandung keteladanan yang senantiasa relevan dengan kehidupan masyarakat sehingga menjadi pendidikan berharga. Para ulama sarat dengan pandangan dan pemikiran yang diperlukan masyarakat dalam penghadapi kehidupan yang senantiasa mengalami perubahan. Jika ulama diidentikkan dengan tokoh tradisional bukan berarti pandangan dan pemikirannya yang jumud tetapi banyak dia membina masyarakat tradisional dalam menghadapi perubahan.

Pengungkapan kembali biografi ulama sangat penting, selain sebagai tanda terima kasih dan penghargaan atas jasa-jasa dan pengabdiannya, juga memperkaya khazanah budaya dan keagamaan sebagai salah satu media komunikasi berkelanjutan dengannya dan merupakan salah satu bentuk pendidikan masyarakat untuk menjadikannya patron moral dan etika dalam kehidupan 
dalam berbagai dimensi, termasuk di dalamnya penyusunan biografinya merupakan bagian dari khazanah keagamaan yang mendapatkan perhatian dari Balai Litbang Agama Makassar.

Berlandaskan pertimbangan tersebut

Balai Litbang Agama Makassar telah melakukan pengkajian tentang ulama. Pada tahun 2011 dilakukan penelitian Biografi Ulama Lokal dan Karya Tulisnya di Kawasan Timur Indonesia. Penelitian ini dan menampilkan 10 orang ulama. Penelitian ini, mengungkap biografi 10 orang ulama sasaran dan menginventarisir hasil karya tulis mereka. Pada tahun 2012 dilakukan lagi penelitian Biografi Ulama Perempuan di KTI dengan menampilkan 8 orang ulama (perempuan) yang masih hidup. Penelitian ini menemukan bahwa kiprah ulama perempuan tidak jauh beda dengan para ulama (laki-laki). Pada tahun 2013 dilanjutkan dengan penelitian Biografi Tokoh Agama di KTI dengan mengangkat 10 orang ulama. Penelitian ini menemukan jasajasa mereka yang nyata dalam membimbing dan membina masyarakatnya. Berbagai peran dan aktivitas keagamaan dan kemasyarakatan terungkap selaku tokoh agama. Meskipun demikian, jumlah ulama yang sudah terungkap biografinya dalam penelitian tersebut ditambah dengan kajiankajian yang telah dilakukan oleh pihak lain, baik perorangan maupun kelembagaan, masih sangat terbatas dibanding dengan jumlah ulama yang telah berjasa dalam membimbing masyarakat dan membina kehidupan mereka di Kawasan Timur Indonesia. Atas dasar pertimbangan tersebut, pada tahun 2015 Bidang Lektur dan Khazanah Keagamaan Balai Litbang Agama Makassar merasa perlu melanjutkan penelitian tentang biografi ulama untuk lebih memperkaya khazanah keagamaan sebagai bagian dari pembinaan kehidupan beragama masyarakat. Salah satu ulama yang belum dikemukakan biografinya adalah KH. Abd. Rahman Pakkanna. Berdasarkan pada latar belakang di atas, permasalahan pokok dalam penelitian ini adalah Bagaimana Kehidupan dan Peran KH. Abd. Rahman Pakkanna dalam Kehidupan Masyarakat di Kabupaten Soppeng?.

\section{Tinjauan Pustaka}

Banyak kajian telah dilakukan oleh berbagai pihak berkaitan dengan ulama dengan metode dan sudut pandang masing-masing. Majelis Ulama Sulawesi Selatan memprakarsai penulisan Biografi Ulama Sulawesi Selatan dengan judul Ulama Sulawesi Selatan, Biografi Pendidikan dan Dakwah
(Ruslan dan Waspada Santing. 2007). Dalam penulisan biografi ini, dilibatkan beberapa penulis, dan berhasil mengungkap biografi 14 orang ulama yang dikenal di Sulawesi Selatan, bahkan sudah ada yang dikenal di tingkat nasional, seperti AG. H. Muhammad As'ad dan AG. H. Ambo Dalle, yang keduanya sudah tercantum dalam buku Ensiklopedi Ulama Nusantara, seperti telah dikemukakan.

Abd. Kadir Ahmad dalam disertasinya yang kemudian dipublikasikan dengan judul Ulama Bugis menyoroti juga ulama sebagai figur penting dalam masyarakat. Yang mendapat sorotan dalam tulisan ini adalah pandangan masyarakat Bugis tentang ulama, pandangan keagamaan ulama, peran ulama dalam dinamika sosial, dan pola hubungan ulama dan masyarakat. Secara singkat dikemukakan profil AG.H.Daud Ismail dan 12 ulama lainnya (Ahmad, 2009).

AG. H. Daud Ismail seorang ulama dari Soppeng dikupas pula dalam Buah Pena Sang Ulama, bersama ulama-ulama lainnya, yaitu Annangguru Muhammad Shaleh (Mandar), KH.Hamzah Manguluang (Wajo), KH.Muhammad Abduh Pabbajah (Pare-Pare), Ust.Abdullah Said (Balikpapan), dan KH.Dja'far Sabran (Samarinda) (As'ad dkk, 2011).

Karena banyaknya ulama yang telah berjasa dalam mendidik dan membina masyarakat Islam, maka ulama yang diungkap dalam berbagai tulisan belum menjangkau semua ulama. Pada sisi lain banyak ulama yang telah disinggung dalam tulisan yang ada tetapi yang terungkap masih terbatas. Berkaitan dengan itu penulisan biografi ulama yang terjangkau oleh para penulis masih relevan, seperti KH. Abd. Rahman Pakkanna.

Ruang lingkup penelitian ini mengacu pada judul yaitu Biografi KH. Abd. Rahman Pakkanna. Biografi dapat diartikan tulisan tentang kehidupan seseorang dan dapat juga dikatakan sebagai sebuah kisah riwayat hidup seseorang. Biografi berisi fakta-fakta dari kehidupan seseorang dan peran pentingnya dalam masyarakat serta informasiinformasi lainnya. Realitas hidup ini dikemukakan secara singkat atau dikisahkan lebih mendetail dengan gaya bercerita yang baik.

Dalam penelitian ini, yang dimaksud dengan ulama adalah seseorang yang telah mendapatkan pengakuan masyarakatnya karena mempunyai pengetahuan yang luas terhadap Islam (mattasi paddisengenna) dan atau dalamnnya pemahaman agamanya (malamung pahanna) yang diabdikan dalam masyarakat. Pengakuan tersebut didasarkan 
pada kemuliaan akhlaknya dan ketinggian moralnya yang tercermin dalam aktivitas serta pengabdian sosial dan keagamaan mereka dalam membina dan membimbing masyarat.

\section{METODE PENELITIAN}

Penelitian ini merupakan penelitian deskriptif kualitatif dengan menggunakan pendekatan sejarah sebagai salah satu acuan dalam penelusuran biografi tokoh (Syamsuddin, 2007: 89). Penelitian dilakukan di Kabupaten Soppeng dan sasarannya ialah KH. Abd. Rahman Pakkanna. Data yang dikumpulkan dalam penelitian ini meliputi: latar belakang keluarga, riwayat pendidikannya (formal dan nonformal), dan pekerjaan atau kegiatan seharihari; aktivitas sosial dan keagamaannya; perannya dalam pendidikan masyarakat; sikap dan pandangan hidunya; serta hasil karyanya yang diwariskan pada masyarakatnya. Sebagai pendukung penelitian ini, sekilas kondisi kehidupan keagamaan masyarakat pada lokasi ulama pernah berkiprah. Sumber data adalah para informan yang memiliki kedekatan dengan KH. Abd. Rahman Pakkanna, seperti hubungan keluarga, hubungan pertetanggaan, hubungan guru-murid, dan hubungan pekerjaan. Juga berbagai pihak lain berkaitan dengan penelitian ini, seperti instansi/pejabat pemerintah, organisasi keagamaan, lembaga atau kelompok masyarakat lainnya. Selain itu, juga dokumen dan kepustakaan yang relevan dengan penelitian, baik berupa tulisan maupun rekaman.

Teknik pengumpulan data yang digunakan, yaitu: Wawancara dengan informan yang relevan yakni keluarga atau kerabat ulama bersangkutan, orang-orang yang memiliki kedekatan dengannya, tokoh masyarakat, dan anggota masyarakat lainnya; Studi pustaka dan dokumen yang berkaitan dengan penelitian. Observasi juga dilakukan dalam membaca lingkungan masyarakat sekitar ulama yang diteliti, terutama kehidupan keagamaannya untuk mendapatkan data penunjang. Sebagai ciri penelitian kualitatif, instrumen utamanya adalah peneliti sendiri, maka pengolahan data dilakukan berbarengan dengan pengumpulan data. Kritik sumber, baik eksternal maupun internal terhadap data yang terkumpul (evidensi) dilakukan pada pengolahan ini. Selanjutnya, data dikategorikan berdasarkan jenis tertentu, kemudian disusun dalam suatu pola atau sistimatika. Analisis data yang dipergunakan sesuai dengan jenis data yaitu deskriptif kualitatif dalam bentuk narasi.

\section{PEMBAHASAN}

Kabupaten Soppeng adalah salah satu kabupaten di Provinsi Sulawesi Selatan yang secara geografis berada di tengah daratan, tidak memiliki pantai. Kabupaten ini diapit oleh 4 kabupaten lainnya, yaitu: Kabupaten Sidrap, Kabupaten Wajo, Kabupaten Bone dan Kabupaten Barru. Wilayah Kabupaten Soppeng yang luasnya hanya $1.500 \mathrm{~km}^{2}$ dan terbagi secara tidak merata pada 8 kecamatan dihuni oleh penduduk (2014) berjumlah 225.512 jiwa terdiri atas laki-laki 106.111 jiwa $(47,05$ \%) dan perempuan sebanyak 119.401 jiwa (52,95\%). Penduduk tersebut tersebar secara tidak merata pada 8 kecamatan (BPS Kabupaten Soppeng 2015).

Kabupaten Soppeng pada masa dahulu merupakan wilayah Kerajaan Soppeng, salah satu kerajaan Bugis di Sulawesi Selatan. Kerajaan Bugis lainnya yang dikenal antara lain: Kerajaan Luwu, Kerajaan Bone, Kerajaan Wajo, dan Kerajaan bersaudara Sidenreng dan Rappang. Kerajaan Bone, Kerajaan Soppeng, dan Kerajaan Wajo dikenal dengan Tellumpoccoe. Ketiga kerajaan Bugis ini diislamkan oleh Kerajaan Gowa, kerajaan orang Makassar di Sulawesi Selatan. Kerajaan Gowa melancarkan sejumlah perang untuk memaksa beberapa kerajaan di Sulawesi Selatan agar menerima Islam.Berturut-turut diislamkan Kerajaan Soppeng (1609), Kerajaan Wajo (1610), dan Keraajaan Bone (1611) (Mappangara dan Irwan Abbas. 2003: 9091). Sejak Islam diterima sebagai agama resmi di Kerajaan Soppeng, Islam menjadi bahagian hidup dari masyarakat. Dalam lontara orang Bugis dikemukakan antara lain: "eppami uangenna padecengie tana. Iami nagenne limampuangeng narapi' mani asellengeng, naripattamatona sara'e, seuani ade'e, maduanna rapangnge, matellunna warie. maeppana bicarae, malimanna sara'e" (empat macam saja yang memperbaiki Negara, barulah dicukupkan lima macamnya ketika sampai pada keislaman dan dimasukkan sara', pertama ade, kedua rapang, ketiga wari', keempat bicara, kelima sara' (Mattulada dalam Taufiq Abdullah (ed). 1983: 232-233).

Dimasukkannya sara' (syariat Islam) sebagai salah satu unsur tatanan masyarakat dan pemerintahan (pangngadereng), agama atau syariat Islam menjadi bagian integratif dalam kehidupan masyarakat. Perpaduan antara unsur adat dan unsur Islam (sinkritisme) sangat erat dan menimbulkan suatu corak tersendiri, sehingga bagi masyarakat umum sulit membedakan secara jelas kedua unsur 
itu. Perpaduan ini terutama terlihat pada upacaraupacara sosial keagamaan. Hal ini dikarenakan oleh sekurang-kurangnya dua hal yaitu: pertama, penyebaran Islam memakai pendekatan atas-bawah atau pendekatan formal; dan kedua corak keagamaan yang dikembangkan adalah bersifat akomodatif. Corak keagamaan demikian ini sisa-sisanya masih terlihat sampai saat ini, terutama pada pelaksanaan upacara siklus hidup, seperti pada kelahiran (mappanololo), perkawinan (mappabbotting) dan kematian (mattampung).

Sejak abad ke-17 Islam menjadi anutan masyarakat Soppeng dan berlangsung sampai sekarang. Meskipun ada di antara orang Bugis Soppeng yang menganut agama lain, namun jumlahnya sangat sedikit. Secara umum di Kabupaten Soppeng, tokoh agama yang terlibat dalam pelayanan keagamaan, khususnya dakwah dan penerangan agama cukup banyak dan bervariasi. Bagi umat Islam, tokoh agama dapat dikelompokkan pada 4 kategori, yaitu: ulama, muballig, khatib, dan penyuluh agama Islam. Tokoh agama yang berpredikat ulama (kiyai atau gurutta) ialah tokoh agama yang sudah mendapat legitimasi oleh masyarakat karena keluasan pengetahuan agamanya dan atau kedalaman pemahaman keagamaannya, dan dedikasinya terhadap pelayanan agama, terutama keikhlasannya.

Sebagaimana pada daerah-daerah lainnya di Sulawesi Selatan, masyarakat Soppeng masih memelihara berbagai upacara tradisional yang diwarisi secara turun temurun. Upacara-upacara ini diwarnai dengan nuansa Islam, sehingga terjadi perpaduan antara dua unsur, yaitu unsur tradisi dan unsur Islam. Sangat sulit membedakan antara kedua unsur itu, sehingga bagi orang awam terkadang menganggap semuanya sebagai unsur agama. Upacara-upacara yang masih dilestarikan oleh masyarakat berkaitan dengan siklus hidup, dengan mata pencaharian, dan dengan peristiwa penting. Di samping upacara-upacara tradisional keagamaan, masyarakat Islam di Soppeng juga memelihara upacara atau perayaan keagamaan, yaitu: kedua hari raya Idul Fitri dan Idul Adha, maulid Nabi Muhammad saw dan Isra-Mi'raj.

\section{Biografi Singkat KH. Abd. Rahman Pakkana Kehidupan Pribadi dan Keluarga}

Pada tahun 1927 di Ganra-Soppeng lahir seorang anak laki-laki dari pasangan suami isteri petani, H. Pakkanna bin La Nusu (Kamo Nusu) dan I Becce. Bayi mungil ini merupakan anak ketiga dari pasangan tersebut yang diberi nama La Damang. Nama ini telah dipergunakan lebih dahulu oleh seorang kali (qadhi) dari Ganra dengan panggilan Kali Damang. Besar dugaan kedua orang tua sang bayi yang baru lahir ini memberi nama tersebut dengan harapan nantinya tumbuh dewasa menjadi tokoh agama.

La Damang adalah anak ketiga dari enam bersaudara, tiga laki-laki dan tiga perempuan. Kakak pertamanya bernama $H$. Muhammad Pakkanna dan kakak keduanya diberi nama I Muna. Adik pertamanya Hj. Hawa, adik keduanya Ahmad (meninggal waktu masih anak-anak), dan adik ketiganya bernama Nimah.

Pada tahun 1949, tepatnya pada hari Senin, tanggal 20 Juni, ketika berumur 22 tahun, H. Abd. Rahman Pakkanna mempersunting dara manis dari keluarga dekatnya bernama St. Rafiah yang usianya masih sangat muda, memasuki 13 tahun. Gadis ini dilahirkan di Ganra pada tahun 1937 dari pasangan La Betta bin La Mattinawang dengan Hj. Hatena binti La Masse. H. Abd. Rahman Pakkanna adalah paman dari St. Rafiah dari pihak ibunya, yaitu I Becce yang bersaudara dengan I Fatimang, ibu dari La Betta.

St.Rafiah adalah putri bungsu dari pasangan La Betta dan Hj. Hatena, meskipun sebenarnya ia pernah memiliki seorang adik, tetapi bayi itu lahir setelah ia menikah, bahkan sudah melahirkan dan ia meninggal saat berusia 4 bulan. Kakak tertuanya bernama Hj. Suherah (Aji Suhe) dan kakak keduanya bernama KH. Abd. Muin.

Dari perkawinan KH. Abd. Rahman Pakkanna dengan $\mathrm{Hj}$. Rafiah lahir 7 orang anak yang semuanya masih hidup sampai sekarang. Semuanya laki-laki kecuali satu orang, yaitu anak kedua. Ketujuh putraputri tersebut sudah menikah dan menghasilkan putra putri kecuali Dr. H. Rusydi Rahman. Secara berturut-turut ketujuh anak itu ialah: Prof. Dr. H. Jalaluddin Rahman; Hj. Nurul Huda; Ir. Mukhtar Rahman; Dr. H. Rusydi Rahman, M.Si; Muh. As'ad Rahman, S.Ag; Mujibur Rahman, S.TP., M.Si; dan Taqiyuddin, ST.

Memperhatikan nama-nama putra-putri tersebut, terlihat jelas bahwa KH. Abd. Rahman Pakkanna berhasil mendidik mereka dengan baik. Semuanya serjana kecuali satu-satunya putrinya, yaitu Hj. Nurul Huda. Hal ini terjadi bukan karena sikap diskriminaif terhadapnya dalam masalah pendidikan, tetapi karena putrinya tersebut mendapatkan jodoh lebih cepat. Meskipun putrinya tersebut bukan keluaran akademik tetapi ia berhasil 
melahirkan sarjana, yaitu tiga dari empat anaknya semuanya sarjana, hanya yang bungsu belum sarjana. Anaknya yang tertua sudah S3 dan yang dua lainnya sudah S2. Keberhasilan-keberhasilan ini tidak terlepas dari bimbingan dan bantuannya serta do'a isterinya Hj. Rafiah.

\section{Riwayat Pendidikan dan Pekerjaan}

H. Pakkanna sebagai seorang muslim yang baik menyadari tanggung jawabnya dalam pendidikan agama anak-anaknya. Pada saat $\mathrm{La}$ Damang mencapai usia 7 tahun (1934 M), karena ia sendiri tidak dapat mengajar langsung anaknya membaca Alquran, maka anaknya dipercayakan kepada H.Syamsuddin (H. Laodding) untuk mengajarnya membaca Alquran.

La Damang adalah murid yang sangat rajin dan pemberani. Ia berangkat mengaji ke rumah gurunya pada subuh hari ketika suasana masih sepi dan gelap. Keinginanya yang keras untuk belajar mengaji mengalahkan rasa takut yang sering menyelimuti seorang anak seusianya. Bahkan sering dialah sendiri yang membuka pintu rumah gurunya. $\mathrm{H}$. La Odding sebagai seorang guru mengaji yang memiliki keikhlasan yang tinggi, dengan senang hati melayani keinginan keras muridnya yang bernama La Damang untuk belajar. Setelah selesai melaksanakan shalat Subuh, ia mengajar mengaji atau membaca Alquran kepada muridnya yang satu ini. Keadaan demikian ini berlangsung sekitar satu tahun, hingga La Damang berhasil tamat mengaji Alquran (temme mangaji) pada tahun 1934.

Pendidikan formal diikuti oleh La Damang ketika berumur 10 tahun (1937). Ia belajar pada Sekolah Rakyat (SR) Paommalimpoe. Kesediaan mengikuti pendidikan pada sekolah ini lagi-lagi memperlihatkan bahwa La Damang adalah anak rajin dan pantang menyerah. Mengapa tidak, SR Paommalimpoe ini berada pada kampung Paommalimpoe di sebelah timur kampung Ganra yang jaraknya sekitar 1,5 dari rumahnya. Pembelajaran di sekolah ini hanya diikuti selama 2 tahun, bukan karena tidak sanggup melanjutkannya, jalan kaki pergi pulang setiap hari sekolah, tetapi ia lebih tertarik belajar ilmu agama pada ustaz Yusuf Usman, seorang anak muda yang energik yang cukup mumpuni dalam dakwah dan pendidikan Islam.

Pada mulanya Ustaz Yusuf Usman yang bertempat tinggal di Lompulle, sekitar $10 \mathrm{~km}$ dari Ganra datang ke Ganra sebagi da'i muda terutama pada bulan suci Ramadhan. Jarak demikian saat itu menyulitkan untuk pergi pulang sehingga masyarakat Ganra mengharapkan agar muballig muda yang masih bujangan ini tinggal di Ganra untuk melakukan misi dakwah yang diembannya. Keinginan masyarakat ini disambut baik oleh Ustaz Yusuf Usman sehingga masyarakat Ganra berterima kasih kepadanya. Tanda terima kasih yang tinggi diwujudkan dengan nyata oleh seorang warga Ganra bernama I Becce, ibu dari La Damang dengan menawarkan kepada Ustaz Yusuf agar bersedia tinggal di rumahnya. Harapan seorang sosok perempuan yang cinta dan hormat kepada orang yang berkemampuan di bidang ilmu agama ini tersambut dengan baik. Ustaz Yusuf bersedia tinggal di rumah I Becce selama berada di Ganra.

Penghargaan yang tinggi kepada orang yang mempunyai ilmu agama (ustaz) diperlihatkan oleh I Becce dengan memberi pelayanan penuh penghormatan, terutama tergambar setiap menyiapkan hidangan makan, baik menu makanannya maupun cara menghidangkannya. Keberadaan guru agama, yang saat itu masih langka, di rumah La Damang dimanfaatkan dengan baik dengan berguru padanya. Bacaan Alqurannya diperlancar ditambah dengan pelajaran agama lainnya. Yang tidak kurang pentingnya dalam pendidikan agama bagi Abd. Rahman Pakkanna ialah diperkenangkannya ikut serta pada gurunya bila pergi berdakwah.

Kenangan yang tak terlupakan bagi La Damang kepada gurunya Yusuf Usman adalah usaha penggantian namanya dengan nama yang bernuansa islami yaitu Abd. Rahman Pakkanna. Agar nama yang baru ini melekat pada diri La Damang maka Ustaz Yusuf mempergunakan nama baru ini bila memanggil namanya. Sejak saat ini, kedua nama ini melekat padanya secara bersamaan, tergantung konteks pemakaiannya. Abd. Rahman Pakkanna dipakai dalam konteks formal dan La Damang dalam konteks keluarga dan masyarakat.

Aktivitas pendidikan agama yang dilakukan oleh Ustaz Yusuf Usman terlihat setelah kawin dengan gadis Ganra bernama I Tawang, sepupu Abd. Rahman Pakkanna. Pada awalnya Ustaz Yusuf memberikan pendidikan agama secara privat kepada Abd. RahmanPakkanna, namun aktivitas ini menarik perhatian masyarakat sehingga banyak anak-anaklainnya yang ikut serta sehingga pengajian dilakukan di masjid Ganra (tempatnya bukan pada masjid sekarang). Pengajian ini merupakan cikal bakal berdirinya MAI Ganra yang selanjutnya berkembang menjadi Perguruan Islam Ganra. 
MAI Ganra secara resmi didirikan pada bulan Agustus 1940 dan berlokasi di masjid Ganra. Berdirinya madrasah ini atas prakarsa para tokoh masyarakat, dan yang utama ialah: Andi Hasan (Sulewatang Ganra), H. Ahmad Adam (Imam Ganra), dan Muh. Aras (tokoh masyarakat). Berdirinya madrasah ini tidak menyebabkan berhentinya pengajian wetonan, tetapi keduanya berjalan beriringan. Muh. Yusuf Usman tanpa pamrih mencurahkan tenaganya semaksimal mungkin untuk memberikan pengajaran agama pada masyarakat Ganra. Pada pagi hari mengajar murid-muridnya di madrasah dan pada malam hari memberikan pengajian wetonan. Semula MAIGanra terdiri atas dua tingkatan, yaitu tingkat Awaliyah (1 tahun) dan tingkat Tahdhiriyah (direncanakan 3 tahun). Kondisi politik pada masa Pemerintahan Jepang tidak kondusif sehingga MAI Ganra berhenti sama sekali dari kegiatan pembelajaran pada penghujung tahun 1943 tanpa berhasil menamatkan murid pada tingkat Tahdhiriyah (As'ad, 1989: 9597).

Setelah itu, Abd. RahmanPakkanna bersama temannya bernama Muh. Said mengunjungi pengajian yang dilakukan oleh AGH. Daud Ismail di Pattojo, sekitar $10 \mathrm{~km}$ dari Ganra. Beliau pindah ke Pattojo sekitar pertengahan 1944 atas permintaan Datu (Raja) Pattojo, Andi Sumange Rukka untuk menjadi guru agama privat bagi diri dan keluarganya. Selain sebagai guru privat, beliau juga memberikan pengajian di masjid Pattojo (As'ad dkk, 2011:40). Pendidikan agama yang diikuti di Pattojo hanyalah pengajian kitab yang dilaksanakan di masjid Pattojo setelah shalat Ashar dan shalat Shubuh. Pada tahun 1945 AGH. Daud Ismail diangkat menjadi Kali (kadhi) di Soppeng dan kedua santri dari Ganra tersebut pidah belajar di Soppeng pada AGH. Daud Ismail.

Ketika mengikuti pengajian kitab di Soppeng yang berlangsung sesudah shalat Ashar dan sesudah shalat Subuh, Abd. Rahman Pakkanna juga mengikuti pendidikan formal pada Almadrasatul Arabiyatul Islamiyah (MAI) Watansoppeng dan berhasil tamat dan memperoleh ijazah tingkat ibtidaiyah pada tahun $1946 \mathrm{M} / 1365 \mathrm{H}$. Pada tahun 1947 Abd. Rahman Pakkanna menunaikan ibadah haji sekaligus melanjutkan pelajarannya di Arab Saudi. Ia mendaftarkan diri pada Almadrasah Asshoulatiyah Alhindiyah bi Makkah Almukarramah pada Al Qism Astsanawy (setingkat Madrasah Tsanawiyah). Setelah belajar satu tahun, ia berhasil naik kelas dua dengan predikat Baik (Dokumen berupa Syahadat al Irtiqa'). Namun kehendak Allah tidak selamanya sesuai dengan keinginan manusia, pada tahun 1948, H. Abd. Rahman Pakkanna harus kembali ke tanah air karena ibundanya sakit selalu mengingat anaknya yang ada di Mekah $(\mathrm{Hj}$. Rafiah,wawancara di Ganra, 4/10/2015).

Pada tahun ini juga, tahun $1948 \mathrm{H}$. Abd. Rahman Pakkanna melanjutkan pendidikannya di tingkat Tsanawiyah pada Madrasah Arabiyah Islamiyah (MAI) Sengkang yang didirikan dan dipimpin oleh ulama besar AGH. Muhammad As'ad (Gurutta Sade). Hanya dalam tempo dua tahun, H. Abd. Rahman Pakkanna berhasil menyelesaikan pendidikannya dan memperoleh ijazah tingkat Tsanawiyah pada tahun 1950.

MAISengkang yang didirikan pada tahun 1930 dan kemudian berubah menjadi Pesantren As'adiyah Sengkang telah berhasil menelurkan banyak ulama yang berperanan dalam pengembangan pendidikan Islam di Sulawesi Selatan dan dalam bidang keagamaan lainnya. Berkaitan dengan hal ini Zainuddin Hamka mengemukakan bahwa dalam buku Setengah Abad As'adiyah tercatat seratus enam puluh alumni As'adiyah yang dianggap memegang peranan penting dalam berbagai bidang. Dari jumlah tersebut, murid langsung beliau yang berjasa mendirikan pesantren di Sulawesi Selatan adalah: 1. AGH. Ambo Dalle (DDI Mangkoso, Pare-Pare, dan Pinrang), 2. AGH. Daud Ismail (Yasrib Soppeng), 3. AGH. Abd. Kadir Khalid, MA (MDIA Ujung Pandang), 4. AGH. Abduh Pabbaja (Al Furqan Pare-Pare), 5. AGH. Abd. Rahman Pakkanna (YPIG Ganra Soppeng), 6. AGH. Abd. Muin Yusuf (Urwatul Wutsqa Rappang Sidrap), 7. AGH. Ahmad marzuki Hasan (Darul Istiqamah Maros), dan 8. AGH. Hamzah Manguluang (Babul Khaer Bulukumba). Ulama alumni As'adiyah yang berkiprah di Pemerintahan jumlahnya cukup banyak. Di Pengadilan Agama tercatat: H. Ya'la Thahir, H. Khalid Husain, H.M. Shaleh Thaha, H. Harun Rasyid, H.M. Akib Siangka, H.M. Hasyim, H. Hamzah Badawi, H. Abdullah Shaleh, H. Andi Rumpang, H. Abd. Razak, dan H. Abd. Hamid. Sebagai kepala Kantor Departemen Agama: H. Yusuf Hamzah, H. Muhammad As'ad Daeng Paewali, H. Abd. Halim, H. Buwaeti Abbas, H. Mujtaba, H. Mangka, H. Abd. Karim Said, BA, H. Abd. Karim Jałar, H. Mustari, dan M. Said (Hamka, 2009: 128130).

Bepulangnya ke Ramatullah AGH. Muhammad As'ad pada tahun 1952 sangat berpengaruh terhadap perjalanan pendidikan $\mathrm{H}$. 
Abd. Rahman Pakkanna karena sejak itu dirasakan hilangnya tempat berguru. Namun demikian, tetap bertahan dan belajar pada ulama lainnya, seperti AGH. Daud Ismail sampai pada tahun 1954 dan kembali ke Ganra Soppeng.

KH. Abd. Rahman Pakkanna tampil di tengah masyarakat sebagai pekerja yang ulet. Tiga jenis profesi yang pernah ditekuninya secara bersamaan dan ketiganya ditekuninya dengan sungguhsungguhdan dilakukannya secara profesional. Pada saat itu, ia tampil sebagai petani yang tangguh, ia juga dikenal sebagai tukang jahit yang piawai, dan sebagai pejuang pendidikan yang ulung $(\mathrm{Hj}$. Rafiah,wawancara di Ganra, 4/10/2015).

\section{Kegiatan dan Aktivitasnya dalam Pembinaan dan Pendidikan Masayarakat.}

KH. Abd. Rahman Pakkanna banyak mencurahkan perhatiannya dalam bidang pendidikan dan pembinaan masyarakat. Karirnya di bidang pendidikan formal dimulai ketika belajar pada tingkat Tsanawiyah di MAI Sengkang. Sementara ia mengikuti pendidikan di tingkat Tsanawiyah, ia diperintahkan oleh Gurutta Sade (Panggilan AGH. Muhammad Asad) untuk mengajar di tingkat ibtidaiyah. Pada mulanya tugas ini terasa sangat berat karena percaya dirinya belum terbina, keraguan pada kemampuan dirinya senantiasa menghantuinya. Namun pada sisi lain, karena amanah dan kepercayaan dari Gurutta Sade yang diyakininya diberikan kepada dirinya karena melihat ada potensi dan kemampuan padanya sehingga keraguan itu mendorongnya untuk membangkitkan percaya dirinya dengan usaha yang sungguh-sungguh.

Ia menerima tugas dan tanggung jawab itu dengan sungguh-sungguh dan penuh usaha. Setiap akan mengajar, ia menghadap lebih dahulu pada Guru Sade untuk mempelajarinya sehingga ia merasa betulbetul menguasai bahan yang akan diajarkan. Usaha demikian ini dihentikannya setelah Gurutta Sade mengatakan tidak perlu engkau selalu menghadap, kemampuanmu sudah cukup untuk melaksanakan tugas dan tanggung jawab mengajar itu.

Strategi mengajar yang diterapkan pada pertama kalinya adalah merendahkan diri tetapi penuh percaya diri. Ia sampaikan kepada murid yang dihadapinya yang rata-rata umurnya tidak jauh beda dari pada dirinya, bahwa ia tidak merasa lebih dari mereka tetapi diberi tanggung jawab oleh gurutta maka harus ia melaksanakannya. Selanjutnya ia tidak menerapkan metode ceramah, tetapi terlebih dahulu menunjuk seorang demi seorang untuk membaca bahan yang diajarkan atau belajar siswa aktif. Karena itu setiap siswa merasa ragu atas kemampuannya untuk melaksanakan tugasnya dan tidak berani bertindak macammacam. Dengan demikian pembelajaran dapat berjalan dengan lancar.

Posisi sebagai ustad, mengajar di tingkat ibtidaiyah dilakukan sampai tahun 1951 dan sejak tahun 1952 dipindahkan mengajar pada tingkat Tsanawiyah dan berlangsung terus setelah Gurutta Sade berpulang ke Rahmatullah sampai tahun 1954. Pada tahun ini, H. Abd. Rahman Pakkanna meninggalkan Sengkang kembali ke Ganra daerah asalnya. Kembalinya ke Ganra tidak berarti meninggalkan dunia pendidikan karena di Ganra sendiri sudah terdapat madrasah yang sangat menbutuhkan guru, yaitu Madrasah Arabiyah Islamiyah (MAI) Ganra.

Pada dekade tahun 1950-an sampai tahun 1960-an, era orde lama, pekerjaan sebagai pegawai negeri, termasuk sebagai guru tidak tergolong pekerjaan yang menjanjikan masa depan. Gaji sebagai pegawai negeri sangat rendah tidak dapat menutupi kehidupan sehari-hari. Bahkan ada pegawai negeri yang menyatakan berhenti dan memilih sebagai pengusaha. Untuk mengatasi kebutuhan rumah tangga keluarganya, $\mathrm{H}$. Abd. Rahman Pakkanna menekuni pekerjaan sebagai tukang jahit profesional, dikenal sebagai tukang jahit jas. Dalam menekuni pekerjaan ini, ia memimpin seorang tukang jahit lainnya, sehingga termasuk punggawa.

Posisi sebagai pemimpin usaha (punggawa) diembannya di bidang pertanian. Ia tampil sebagai petani yang ulet dengan menggarap sawah sendiri dan memimpin dua orang petani. Setiap hari pekerjaan sebagai petani yang pertama dilakukannya. Sehabis shalat subuh dan minum kopi, KH. Abd. Rahman Pakkanna menuju ke sawah garapannya yang tidak jauh dari rumaahnya dan kembali sebelum jam sekolah dimulai karena ia akan melaksanakan tugasnya sebagai pendidik.

Di samping ketiga profesi tersebut, $\mathrm{KH}$. Abd. Rahman Pakkanna punya keterampilan di bidang pertukangan kayu. Meskipun ia tidak menekuni pekerjaan ini sebagai profesinya tetapi banyak dimanfaatkan terutama dalam pembangunan madrasah yang dipimpinnya, yaitu Perguruan Islam Ganra dan juga pembangunan masjid Ganra. Keahliannya di bidang pertukangan kayu ini sering dipergunakan dalam membantu masyarakat yang 
membutuhkan, terutama dalam pengukuran dan pemilihan bahan.

KH. Abd. Rahman Pakkanna adalah seorang ulama yang mempunyai keterampilan di bidang pertukangan, terutama memilih dan mengukur kayu bangunan. Keterampilan ini banyak dimanfatkan dalam pembangunan fisik sarana keagamaan masyarakat, yaitu masjid Ganra dan Perguruan Islam Ganra. Pada pembangunan masjid Ganra, sebelum direnovasi, dialah yang banyak berperan, yang dipercayakan pengurus untuk mengurus bahan bangunannya terutama kayunya.

\section{Hasil Karya yang Diwariskan pada Masyarakat;}

Hasil karya KH. Abd. Rahman Pakkanna yang paling menonjol adalah di bidang pendidikan, Yayasan Perguran Islam Ganra. Meskipun yang berjasa pada pembinaan perguruan Islam ini bukan hanya dia satu-satunya, tetapi jasanya sangat besar. Yayasan Perguruan Islam Ganra, sebagai lembaga pendidikan swasta, dalam perjalanan hidupnya yang cukup panjang sejak tahun 1940 membutuhkan perjuangan keras dari masyarakat Ganra terutama para pengurusnya. Sebagaimana lazimnya, pengelolaan suatu lembaga pendidikan, membutuhkan sarana prasarana fisik, terutama berupa gedung tempat belajar. Juga membutuhkan tenaga pengajar yang melayani proses pembelajaran bagi murid/siswa. Selain itu tentunya sangat membutuhkan pembiayaan untuk moubilernya dan untuk menggaji para tenaga pendidiknya.

KH. Abd. Rahman Pakkanna sekembalinya dari Sengkang dan menetap di Ganra sejak tahun 1954 sudah mengabdi pada MAI Ganra untuk memenuhi harapan pengurusnya dan masyarakat Ganra. Peranan dan tanggung jawab besar sebagai ketua pengurus perguruan Islam ini dibebankan padanya sejak tahun 1955. Pucuk pimpinan lembaga perguruan Islam di Ganra ini diterima di atas pundaknya karena rasa tanggung jawab yang sangat besar terhadap pendidikan masyarakat.

Berbagai upaya untuk memajukan lembaga pendidikan Islam ini dilakukannya atas dukungan pengurus lainnya dan masyarakat Ganra. Kerja keras yang dilandasi oleh keikhlasan adalah modal utama dalam menjalankan upaya besar dan sulit ini. KH. Abd. Rahman Pakkanna mampu memobilisasi kekuatan masyarakat yang tergolong sangat terbatas dari segi finansial. Sebagai masyarakat tani, masyarakat Ganra pada umumnya hanya mengandalkan hasil pertanian. Meskipun ada di antaranya yang bergerak di bidang usaha dagang tetapi tidak termasuk pedagang bermodal.

Berbagai usaha yang tergolong inovatif telah diupayakan dalam mengumpul dana dari masyarakat untuk pembangunan gedung yang sangat dibutuhkan untuk proses pembelajaran. Pada saat itu, pembangunan fisik gedung dilakuakan masyarakat secara mandiri dan mesin penggerak utamanya adalah KH. Abd. Rahman Pakkanna. Beliau adalah pemikir praktis yang kreatif. Untuk mengumpulkan dana dari masyarakat saat itu, ada 4 usaha yang dilakukan oleh pengurus, yaitu: menggalakkan pengumpulan zakat harta setiap habis panen padi; melakukan peternakan ayam; masyarakat diajak menanam sebuah pohon pisang di lahannya untuk Perguruan Islam Ganra, dan pengumpulan beras dari ibu rumah tangga setiap memasak di rumahnya.

Upaya terakhir ini sangat inovatif dan hasilnya cukup lumayan. Setiap ibu-ibu rumah tangga yang ingin memasak di rumahnya untuk keluarganya, setelah beras yang mau dimasak ditakar, disisihkan segenggam untuk diinfakan ke Perguruan Islam Ganra. Bagi para ibu-ibu sebelumnya ditanamkan keyakinan bahwa dengan mengharapkan berkah dari Allah atas keikhlasannya, nasi hasil masakannya tidak akan terasa kurang dari biasanya (Hj. Arifah,wawancara di Ganra, 8/10/2015).

\section{Sikap dan Pandangan Keagamaannya}

KH. Abd. Rahman Pakkanna sangat hormat kepada gurunya sebagaimana watak seorang santri. Sekali sebagai murid tetap sebagai murid meskipun memiliki prestasi yang secara lahiriyah melebihi guru. Sikap ini diaplikasikannya terhadap gurunya Muh. Yusuf Usman. Perbedaan orientasi keagamaannya tidak mengurangi penghormatannya kepada gurunya tersebut.

Orientasi keagamaan yang dianutnya adalah faham Ahlusunnah wal Jamaah, sebagaimana yang dianut mayoritas pesantren di Sulawesi Selatan. Ia sangat toleran dalam menyikapi masalah khilafiyah. Sesuatu kebiasaan yang mentradisi dalam masyarakat, bila tidak prinsipil tidak dirubahnya, seperti shalat sunnat qabliyah Magrib. Pada waktu yang lalu shalat sunnat ini tidak dilakukan di masjid Ganra, namun suatu waktu ada jemaah yang mempertanyakaannya karena menyaksikan di tempat lain jemaah masjid melaksanakannya, dan ia menjelaskan bahwa memang ada salat sunnat sebelum Magrib. Sejak saat itu masyarakat Ganra 
sepakat melaksanakannya sampai saat ini. Demikian pula kebiasaan masyarakat yang mentradisi dan tidak jelas larangannya dibiarkan berjalan, meskipun ia sendiri tidak melakukannya, seperti kebiasaan masyarakat melakukan pesta kematian dengan memotong hewan ternak (mattampung) tidak dilarang masyarakat melakukannya, tetapi ia sendiri tidak melakukannya bila ada keluarganya yang meninggal.

Sekali layar terkembang pantang surut sebelum mencapai pulau idaman. Prinsip hidup ini diterapkannya dalam hidupnya dan berusaha disosialisasikannya kepada anak-anaknya. Ia memberi nasehat: Kumutengngaini seddie jama-jamang ajanna mupappesaui narekko deq napura (Jika engkau mengerjakan sesuatu jangan menghentikannya sebelum selesai).

Percaya diri dan tidak bergantung pada orang lain merupakan prinsip hidup lainnya yang merupakan karakter yang melekat padanya. Apabila sesuatu dapat dilakukannya sendiri, ia tidak akan minta bantuan pada orang lain meskipun anak isteri sendiri. Sebelum pergi ke sawah pada pagi hari, ia sendiri membuat kopi yang akan diminumnya, cukup disiapkan air panas dalam termos. Rasa capek pada betis yang dirasakannya diusap sendiri dengan betisnya yang lain, tidak meminta anak isterinya untuk menginjak-injaknya. Ia sering memberi nasehat: mupuamatengengpi gaue nappako mellau (nanti mengancam jiwamu baru kau meminta).

Rasa syukur senantiasa dijadikan bagian dari hidupnya dan berusaha ditanamkan kepada anakanaknya. Untuk memelihara rasa syukur ini, sikap hidup yang ditanamkan baik pada dirinya mapun pada anak-anaknya ialah sikap hidup yang diajarkan Rasulullah SAW: urusan lino akkita liaawako, urusan akherat akkita liasekko (kalau urusan dunia melihat ke bawah, kalau urusan akherat melikat ke atas). Sikap lain untuk memelihara rasa syukur ini adalah: arennuko narekko engka tau mellau riiko, magana narekko iko mellau kutauwe (bergembiralah jika ada orang meminta kepada engkau, dari pada engkau yang meminta kepada seseorang). Manifestasi rasa syukur demikian ini adalah ringan tangan untuk membantu orang yang butuh.

Untuk mendapatkan rezki dari Allah harus bekerja keras. Hal ini merupakan bagian dari hidupnya, sebagaimana telah digambarkan dengan berbagai profesiyang ditekuninya. Namun demikian, disadari pula bahwa usaha manusia hanya prasyarat untuk mendapatkan rezki itu karena kewenangan penentuannya di tangan Allah. Karena itu manusia harus mengharap dan berdoa kepada Allah setelah ia berusaha. Ia mengajarkan kepada anak-anaknya zikir dan doa memudahkan rezki. Amalan untuk memudahkan rezki: membaca Surat Al Waqiah 40 kali setiap hari sampai 40 hari berturut. Zikir lainnya yang diakuinya baik diamalkan dan mujarrabat: membaca surat Yaasin 7 kali sesudah shalat Asar, dan 143 kali sesudah shalat subuh.

Keikhlasan yang tinggi yang dimilikinya merupakanspiritkerjayangmendorongkeaktifannya bekerja tanpa lelah dalam mengurusi agama Allah. Keikhlasan yang tinggi ini menyebabkan keraguan dalam dirinya untuk menjadi pegawai negeri setelah terbuka peluang baginya. Jangan sampai sebagai pegawai negeri yang digaji oleh pemerintah mengurangi keikhlasannya. Karena itu, sebelum merintis jalan untuk menjadi pegawai negeri terlebih dahulu menghadap pada gurunya AGH. Daud Ismail untuk meminta petunjuk. Pernyataan beliau tentang hubungan keikhlasan dengan posisi sebagai pegawai negeri dengan mengatakan mancaji pegawai pallanggana ikhlas-e. Jaminan hidup dari pemerintah harus menjadi pendorong untuk bekerja lebih baik.

\section{Pandangan dan Sikap Masyarakat Terhadapnya}

KH. Abd. Rahman Pakkanna dikenal oleh masyarakat sebagai seorang ulama Fiqih atau ulama Syariat yang luas pengetahuan agamanya, bukan seorang ulama Tarikat yang mempunyai pengikut tarikatnya. Berkaitan dengan itu, masyarakat menjadikannya sebagai panutan dalam beribadah, tempat bertanya berbagai hal masalah agama Islam. Apabila ada masalah fiqih yang dilihat atau disaksikan oleh masyarakat berbeda dengan yang biasa dilakukannya, ditanyakanlah kepadanya, baik pada pengajian halaqah di masjid maupun datang langsung ke rumahnya. Beliau memberikan jawaban atau penjelasan yang sangat bijaksana dan toleran.

Masyarakat mengakui keikhlasan beliau dalam mengurus agama Allah sehingga masyarakat memercayainya tanpa keraguan. Modal spiritual masyarakat inilah yang membawa kesuksesan dalam membangun agama Allah, melalui pembangunan Perguruan Islam Ganra maupun pembangunan Masjid Ganra. Berkaitan dengan itu, masyarakat memandang beliau sebagai orang yang amanah, dipercaya sepenuhnya oleh masyarakat. Berbarengan dengan itu, masyarakat mengakui pula keahlian beliau dalam masalah pertukangan kayu sehingga sangat menunjang pembangunan fisik kedua sarana keagamaan tersebut. 
Ketiga modal sosial, sifat ikhlas, amanah, dan keterampilan tersebut menunjang bahkan memudahkan pembangunan fisik yang sangat dibutuhkan saat itu dalam kondisi ekonomi masyarakat yang terbatas. Setiap pembangunan fisik keagamaan yang dilakukan tidak perlu dengan modal yang tersedia sebelumnya. Banyak pembangunan sarana atau prasarana dilakukan dengan mengandalkan modal sosial tersebut. Perencanaan disampaikan kepada masyarakat, dan masyarakat menerimanya dengan baik, dengan kesediaan berpartisipasi sesuai kemampuannya.

Sebagai masyarakat tani yang penghasilannya mengandalakan hasil panen pada jangka waktu tertentu, pertama mereka mencatatkan kesanggupan atau jumlah yang akan disumbangkan yang pembayarannya sesudah panen sebagai infaq. Pengakuan ini memberikan rasa optimis bagi pengurus untuk melakukan pembangunan yang direncanakan. Bahan-bahan bangunan yang dibutuhkan oleh suatu pembangunan pisik banyak berupa pinjaman dari pengusaha yang diusahakan oleh KH. Abd. Rahman Pakkanna. Mereka percaya kepada beliau sehingga bahan apapun yang ada dan dibutuhkan diserahkan kepadanya untuk dipergunakan. Dan kenyataannya bahan itu terbayar dengan baik sesudah itu, dan tidak pernah sesorangpun merasa dirugikan.

Khusus dari seorang muridnya bernama $\mathrm{H}$. Ahmad Patangngari memandang beliau adalah sosok guru yang sangat memperhatikan pendidikan muridnya. Dorongan dan bantuan kepadanya dirasakan saat akan melanjutkan pendidikannya di Makassar. Suatu pengalaman spiritual yang dirasakannya saat menunaikan ibadah haji pada tahun 2007. Saat berada di Kota Madinah pada malam terakhir, Ia dalam keadaan sadar bertemu dengan sang guru yang sangat dicintainya, di asrama yang ditempatinya menjelang berangkat menunaikan shalat subuh dan sempat berbincaangbincang beberapa saat. Sang guru yang secara lahiriyah berada di Ganra lebih dahulu turun dari hotel dan menghilang dari pandangannya. Setelah kembali ke Indonesia, sengaja datang ke Ganra menyampaikan hal itu kepada guru yang dicintainya itu, dan dinasehatinya supaya hal itu jangan dibesarbesarkan (Wawancara via telepon, 10/10/2015).

\section{PENUTUP}

KH. Abd. Rahman Pakkanna adalah anak petani yang berhasil menjadi ulama. Kecintaannya terhadap ilmu agama sejak kecil mengantarnya untuk mencapai hal itu. Pengajian khalaqah dari AGH Daud Ismail merupakan modal utama baginya ditambah dengan pengajian di Makkah selama satu tahun. Atas dukungan isterinya $\mathrm{Hj}$. Rafiah berhasil membina rumah tangga dan sukses mendidik anak-anaknya sehingga semuanya menjadi sarjana kecuali anak perempuan satu-satunya.

KH. Abd. Rahman Pakkanna termasuk ulama serba bisa dan pekerja profesional. Selain sebagai tokoh pendidik yang tekun, juga sebagai petani yang sukses, sebagai tukang jahit profesional, dan tukang kayu yang pintar. Ia berperan besar dalam membina dan mendidik masyarakat. Selain sebagai guru dan pimpinan Perguruan Islam Ganra, juga sebagai pemikir praktis yang banyak mengurusi pembangunan fisik keagamaan, yaitu perguruan Islam Ganra dan masjid Ganra. Hasil karyanya yang telah diwariskan olehnya kepada masyarakat yang berbentuk fisik adalah kedua lembaga keagamaan tersebut, yaitu Perguruan Islam Ganra dan Masjid Ganra. Meskipun bukan karyanya secara sendirian, tetapi peranannya sangat besar.

KH. Abd. Rahman Pakkanna sangat menghormati gurunya, memiliki sikap toleran yang tinggi dalam masalah agama, dan memelihara kemandirian dalam kehidupan sehari-hari. Predikatnya sebagai pegawai negeri tidak mengurangi keikhlasannya dalam bekerja. Ia dihormati oleh masyarakatnya sebagai anre gurutta dan menjadi panutan dan rujukan masyarakat dalam masalah agama dan masalah sosial, bahkan ekonomi. Masyarakat sangat percaya padanya dan kepercayaan ini merupakan modal sosial yang sangat menunjang pembangunan fisik keagamaan di Ganra.

\section{UCAPAN TERIMA KASIH}

Penulis mengucapkan terima kasih kepada Kepala Balai Penelitian dan Pengembangan Agama Makassar atas perkenannya memberikan kesempatan dan pembiayaan sehingga penelitian ini dapat terlaksana dengan baik. Kepada semua pihak yang telah memberikan bantunnya sehingga penelitian ini dapat terselesaikan, terkhusus keluarga besar Almarhum KH. Abd. Rahman Pakkanna. Terakhir terima kasih kepada Redaksi Al-Qalam atas pemuatan hasil penelitian ini sebagai upaya publikasi yang pada gilirannya menjadi bahan bacaan bagi masyarakat. 


\section{DAFTAR PUSTAKA}

Abdullah, Taufik (ed). 1983. Agama dan Perubahan Sosial. Cet. I. Jakarta: CV. Rajawali bekerja sama dengan yayasan Ilmu Ilmu Sosial (YIIS).

Ahmad, Abd. Kadir. 2009. Ulama Bugis. Cetakan I. Makassar: Indobis.

Al- Ashfahani, Ra>ghib. t.th. Al Mufradhat. Beirut: Dar al fikr.

Al-Husain Ahmad, Abu ibn Faris ibn Zakariya.t.th. Mu'jam Maqayis al-Lugah. Bairut: Dar al-Fikr.

As'ad, Muhammad. 1989. "Madrasah dan Pembangunan Masyarakat: Studi tentang Perkembangan dan Partisipasi Perguruan Islam Ganra" dalam Laporan Hasil Penelitian Studi Sosial dan Keagamaan di Sulawesi Selatan Seri I Pesantren dan Madrasah. Ujung Pandang: Balai Penelitian Lektur Keagamaan Ujung Pandang.

As’ad, Muhammad dkk. 2011. Buah Pena Sang Ulama. Jakarta: Indobis.

Hamka, Zainuddin. 2009. Corak Pemikiran Keagamaan Gurutta H. Muh. As'ad Al-Bugisi. Jakarta: Puslitbang Lektur Keagamaan Badan Litbang dan Diklat Departemen Agama RI.
Horikoshi, Hiroko. 1987. Kyai dan Perubahan Sosial. Cetakan Pertama. Jakarta: P3M.

Ibn Manzur al-Afriqi, Muhammad Ibn Mukrim ibn. t.th. Lisan al-Arab. Bairut: Dar Sa>dir.

Kantor Statistik Kabupaten Soppeng. Kabupaten Soppeng dalam Angka, Tahun 2014. Watan Soppeng. 2015.

Mappangara, Suriadi dan Irwan Abbas. 2003. Sejarah Islam di Sulawesi Selatan. Cetakan Pertama. Makassar: Lamacca Press.

Mattulada. Islam di Sulawesi Selatan.dalam Taufiq Abdullah (ed.). 1983. Agama dan Perubahan Sosial. Cetakan Pertama. Jakarta: CV Rajawali Bekerjasama dengan Yayasanj Ilmu-Ilmu Sosial (YIIS).

Ruslan, Muhammad dan Waspada Santing. 2007. Ulama Sulawesi Slatan: Biografi Pendidikan dan Dakwah. Makassar: Komisi Informasi dan Komunikasi MUI Sulawesi Selatan.

Syamsuddin, Helius. 2007. Metodologi Sejarah. Yogyakarta: Penerbit Ombak.

Turmudi, Endang. 2004. Perselingkuhan Kiai dan Kekuasaan.Cetakan I. Yogyakarta: LkiS. 